\title{
Analisis Pemasaran Susu Segar di Kabupaten Klaten
}

\author{
Sugiharti Mulya Handayani ${ }^{1}$ dan Ivana Nurlaila ${ }^{2}$ \\ ${ }^{1}$ Jurusan Agribisnis, Fakultas Pertanian, Universitas Sebelas Maret, Jl. Ir. Sutami 36 A Surakarta 57126 \\ ${ }^{2}$ Dinas Pertanian Kab. Klaten, Jl. Perintis Kemerdekaan km 3, Klaten
}

\begin{abstract}
ABSTRAK
Penelitian bertujuan untuk mengetahui saluran pemasaran dalam pemasaran susu segar di Kabupaten Klaten, besarnya biaya, keuntungan, margin pemasaran serta efisiensinya. Metode dasar yang digunakan adalah deskriptif analitis dan purposive sampling dengan Desa Kayumas Kecamatan Jatinom sebagai dipilih daerah penelitian. Sampel berjumlah 30 peternak yang diambil dengan metode sample random sampling. Sampel pedagang diambil secara snowball sampling terdiri dari 2 pedagang pengumpul, 3 pedagang pengecer dan 1 pedagang perantara. Data yang digunakan adalah data primer dan sekunder yang diambil pada bulan April 2010 dengan teknik wawancara, pencatatan dan observasi. Analisis data menggunakan cost margin analysis. Dari hasil penelitian dapat disimpulkan ada dua pola saluran pemasaran susu segar yaitu, saluran I: peternak $\rightarrow$ TPS $\rightarrow$ KUD $\rightarrow$ IPS, home industry, pedagang pengecer, dan konsumen. Saluran II : peternak $\rightarrow$ pedagang pengumpul $\rightarrow$ pedagang luar Kecamatan Jatinom. Pada saluran I total biaya pemasaran adalah Rp. 263,76, keuntungan Rp. 143,26 dan margin pemasaran Rp. 328,26 per liter. Untuk saluran pemasaran II total biaya pemasaran Rp. 52,93, keuntungan Rp. 60,07 dan margin pemasaran Rp. 81,50 per liter. Kedua saluran pemasaran sudah efisien dengan nilai farmer's share 89,06 \% untuk saluran I dan 97,24 \% untuk saluran II.
\end{abstract}

Kata kunci: biaya, margin, keuntungan, efisiensi pemasaran, farmer's share

\section{Analysis of Fresh Milk Marketing in Klaten}

\begin{abstract}
This study aimed to determine the marketing channels of fresh milk in Klaten, costs, benefits, marketing margin and efficiency. The basic method used was the descriptive analysis and purposive sampling with the Kayumas Village, Jatinom was selected as a place for the research. In total, 30 dairy farmers were taken as samples by random sampling method. Meanwhile, traders samples taken by snowball sampling consisted of two traders, 3 and 1 meddle retailers. The data used were primary and secondary data taken in April 2010 with interview techniques, recording and observation. Data was analyzed using cost margin analysis.The results of this study showed that there were two patterns of fresh milk marketing channels. Channels I: dairy farmers $\rightarrow$ TPS $\rightarrow$ KUD $\rightarrow$ IPS, home industry, retailers and consumers. Channel II: dairy farmers $\rightarrow$ collectors $\rightarrow$ traders from outside of Jatinom. In the first line the total marketing cost was Rp. 263.76, total marketing profit was Rp. 143.26 and marketing margins was Rp. 328.26 per liter. For marketing channel II total marketing cost was Rp. 52.93, total marketing profit was Rp. 60.07 and marketing margins was Rp. 81.50 per liter. Both of the channels were efficient with the farmer's share of $89.06 \%$ for channels I and $97.24 \%$ for channel II.
\end{abstract}

Keywords: cost, margin, profit, efficiency, marketing, farmer's share 


\section{PENDAHULUAN}

Indonesia adalah negara agraris, dengan jumlah penduduk sebagian besar bermata pencaharian di bidang pertanian, sedangkan kegiatan pertanian itu sendiri meliputi pertanian tanaman pangan, perkebunan, perikanan dan peternakan. Pencapaian sasaran pembangunan sub sektor peternakan melibatkan peran serta pemerintah melalui berbagai program kegiatan untuk mencapai tujuan pembangunan peternakan. Sasaran pembangunan sub sektor peternakan yang ditetapkan dan diprioritaskan pada peningkatan populasi ternak, penyediaan susu, daging dan telur sebagai konsumsi dan meningkatkan kelembagaan informasi pasar untuk memperpendek jarak antara konsumen dan produsen. Usaha peternakan sapi perah merupakan salah satu usaha peternakan yang cukup berperan dalam perekonomian masyarakat pedesaan. Peternakan sapi perah merupakan salah satu bagian dari sub sektor peternakan yang diharapkan dapat menjadi tulang punggung dalam penyediaan protein hewani, karena salah satu tujuan dari pemerintah dalam mengembangkan sapi perah adalah untuk meningkatkan pendapatan peternak (Sudono et al., 2003).

Menurut Nur et al. (2007), seiring dengan laju pertumbuhan penduduk, tuntutan permintaan masyarakat terhadap kebutuhan susu sebagai sumber protein hewani cenderung mengalami peningkatan dari tahun ketahun, ini disebabkan meningkatnya kesadaran masyarakat akan pentingnya penyediaan gizi bagi terciptanya kesehatan manusia dan kondisi manusia yang semakin membaik.

Susu segar adalah bahan pangan yang perisable (mudah rusak), karena mempunyai kadar air tinggi sekitar $87 \%$ - $90 \%$ serta mempunyai nilai nutrisi yang lengkap sehingga baik untuk konsumsi manusia, hewan dan mikroorganisme, oleh karena itu perlu dilakukan pengolahan untuk mempertahankan kualitasnya. Teknologi pengolahan susu segar disamping menghambat kerusakan juga untuk penganekaragaman bahan pangan, karena dengan proses pengolahan kerusakan secara fisik, kimia, dan mikrobiologis akan dapat dicegah dan sekaligus dapat menambah nilai ekonomis dari produk tersebut dan selanjutnya supaya dapat mempertahankan kualitasnya (Khotimah, 2009).

Perkembangan di sektor peternakan khususnya sapi perah memegang peranan sangat penting bagi masyarakat. Usaha peternakan sapi perah diharapkan menjadi peluang dalam mengembangkan agribisnis. Kabupaten Klaten adalah salah satu kabupaten yang sebagian penduduknya bermata pencaharian sebagai peternak sapi perah. Didukung adanya pabrik pengolahan susu di Kabupaten Klaten membuat usaha peternakan sapi perah semakin berkembang. Berikut ini adalah data mengenai jumlah produksi susu segar di Kabupaten Klaten mulai tahun 2004 2008.

Dari 26 Kecamatan yang ada di Kabupaten Klaten, hanya 5 Kecamatan yang terdapat peternak sapi perah. Dan dari 5 Kecamatan tersebut, Kecamatan Jatinom merupakan Kecamatan dengan jumlah produksi susu segar terbanyak yaitu 2.670 .783 liter/tahun.

Pemasaran produk adalah satu komponen pasca produksi yang perlu mendapatkan perhatian lebih karena pemasaran merupakan salah satu kunci dalam pengembangan usaha. Sebagai komoditas yang mudah rusak (perisable), pemasaran susu segar harus mendapatkan perhatian yang serius. Panjang pendek saluran pemasaran akan menentukan kualitas susu segar sehingga akan berpengaruh terhadap besar kecilnya biaya, keuntungan, margin pemasaran serta efisiensinya.

Dengan permasalahan di atas, maka penelitian ini bertujuan untuk mengetahui saluran pemasaran yang digunakan dalam pemasaran susu segar di Kabupaten Klaten, besarnya biaya, keuntungan, margin pemasaran serta efisiennya. 
Tabel 1. Jumlah Produksi Susu Segar Di Kabupaten Klaten Tahun 2004 sampai 2008

\begin{tabular}{llc}
\hline No. & Kecamatan & Jumlah Produksi Susu Segar (Liter) \\
\hline 1. & Manisrenggo & 138.564 \\
2. & Karangnongko & 257.841 \\
3. & Tulung & 228.568 \\
4. & Jatinom & $\mathbf{2 . 6 7 0 . 7 8 3}$ \\
5. & Kemalang & 316.784 \\
\hline Jumlah Total Tahun 2008 & $\mathbf{3 . 6 1 2 . 5 4 0}$ \\
& Tahun 2007 & 3.006 .677 \\
& Tahun 2006 & 2.698 .270 \\
& Tahun 2005 & 2.602 .880 \\
& Tahun 2004 & 3.005 .700 \\
\hline
\end{tabular}

Sumber : BPS Kabupaten Klaten, 2008

\section{MATERI DAN METODE}

\section{Metode Dasar dan Pengambilan Sampel}

Metode dasar yang digunakan dalam penelitian ini adalah metode deskriptif analitik. Teknik pelaksanaannya menggunakan metode survey. Data yang digunakan dalam adalah data primer dan sekunder yang dikumpulkan pada bulan April 2010.

Secara purposive dipilih Kecamatan Jatinom sebagai daerah penelitian dan secara purposive pula dari Kecamatan Jatinom dipilih Desa Kayumas. Pemilihan daerah penelitian dengan pertimbangan merupakan daerah dengan jumlah peternak dan ternak terbesar di Kabupaten Klaten.

Responden yang diambil dalam penelitian ini berjumlah 30 orang peternak dari 365 peternak yang ada di Desa Kayumas. Syarat yang menentukan peternak dapat dipilih sebagai responden adalah mempunyai sapi perah dan menjual hasil produknya berupa susu segar. Pemilihan responden dilakukan dengan simple random sampling dimana dengan metode ini semua peternak di Desa Kayumas mempunyai kesempatan yang sama untuk dipilih sebagai sampel. Teknik pelaksanaannya menggunakan metode undian.

$$
\text { Untuk menentukan lembaga }
$$
pemasaran digunakan metode snowball sampling yaitu penarikan sampel tingkat pertama (peternak) dengan cara simple random sampling, kemudian lembaga pemasaran berikutnya ditentukan dengan mengikuti arus pergerakan pemasaran susu segar sampai pada konsumen akhir.

\section{Metode Analisis Data}

Analisis biaya pemasaran dan margin pemasaran ditingkat lembaga dalam saluran pemasaran digunakan alat analisis biaya dan margin pemasaran (cost margin analysis) yaitu dengan menghitung besarnya biaya, keuntungan, dan margin pemasaran pada tiap lembaga perantara pada berbagai saluran pemasaran.

\section{Biaya, Keuntungan dan Margin Pemasaran}

\section{a. Biaya Pemasaran}

Besarnya biaya pemasaran susu segar dapat dihitung dengan menggunakan rumus sebagai berikut:

$\mathrm{Bp}=\mathrm{Bp} 1+\mathrm{Bp} 2+\mathrm{Bp} 3+\ldots \ldots . .+\mathrm{Bpn}$

Keterangan :

Bp: Biaya pemasaran susu segar

Bp1, Bp2, Bp3,..,Bpn : Biaya pemasaran susu segar tiap-tiap lembaga pemasaran susu segar

$$
1,2,3, \ldots . . n: \text { Jumlah Lembaga }
$$

\section{b. Keuntungan Pemasaran}

Besarnya keuntungan pemasaran susu segar dapat dihitung dengan menggunakan rumus sebagai berikut :

$\mathrm{Kp}=\mathrm{Kp} 1+\mathrm{Kp} 2+\mathrm{Kp} 3+\ldots \ldots .+\mathrm{Kpn}$ 
Keterangan :

$\mathrm{Kp}$ : Keuntungan pemasaran susu segar

Kp1, Kp2, Kp3,......Kpn: keuntungan pemasaran tiap lembaga pemasaran susu.

\section{c. Margin pemasaran}

Margin pemasaran adalah selisih harga ditingkat produsen dan tingkat konsumen. Secara sistematis margin pemasaran dirumuskan sebagai berikut:

$\mathrm{Mp}=\mathrm{Pr}-\mathrm{Pf}$

Keterangan :

Mp: Margin pemasaran susu segar (Rp/liter)

Pr: Harga susu segar ditingkat konsumen (Rp/liter)

Pf: Harga susu segar yang diterima produsen (Rp/liter)

Margin yang diperoleh pedagang perantara dari sejumlah biaya pemasaran yang dikeluarkan dan keuntungan yang diterima oleh pedagang perantara dirumuskan sebagai berikut:

$M p=B p+K p$

Keterangan :

M p: Margin pemasaran susu segar (Rp/liter) Bp: Biaya pemasaran susu segar (Rp/liter)

$\mathrm{Kp}$ : Keuntungan pemasaran susu segar (Rp/liter)

\section{Efisiensi Pemasaran}

Efisiensi pemasaran dalam saluran pemasaran dapat dihitung dengan nilai persentase dari persentase margin pemasaran dari masing-masing saluran pemasaran digunakan rumus sebagai berikut :

a. Persentase Margin Pemasaran

$\mathrm{Mp}=\left(\frac{\operatorname{Pr}-P f}{\operatorname{Pr}}\right) x 100 \%$

Keterangan :

$\mathrm{Mp}=$ Margin pemasaran

$\mathrm{Pf}=$ Harga ditingkat produsen (peternak)

$\mathrm{Pr}=$ Harga ditingkat konsumen b. Bagian yang Diterima Produsen

$\mathrm{F}=\left(1-\frac{\mathrm{M}}{\mathrm{Pr}}\right) \times 100 \%$

Keterangan :

$\mathrm{F} \quad=$ Bagian yang diterima produsen (peternak)

$\mathrm{Mp}=$ Margin pemasaran

$\operatorname{Pr} \quad=$ Harga ditingkat konsumen

Efisiensi pemasaran secara ekonomi dapat diketahui dari besarnya bagian yang diterima produsen dan persentase margin pemasaran yang dinyatakan dalam persen (\%). Pemasaran susu segar dianggap efisien secara ekonomis apabila saluran pemasaran mempunyai nilai persentase margin pemasaran yang rendah, tetapi mempunyai nilai persentase bagian yang diterima produsen (farmer's share) tinggi. Menurut Rasyaf dalam Abadi (2007), bila bagian yang diterima produsen $>50 \%$ maka pemasaran dikatakan efisien, dan bila bagian yang diterima produsen $<50 \%$ berarti pemasaran belum efisien.

\section{HASIL DAN PEMBAHASAN}

\section{Identitas Peternak Responden}

\section{a. Umur Peternak Responden}

Berdasarkan Tabel 2 dapat diketahui bahwa semua peternak responden di Desa Kayumas Kecamatan Jatinom Kabupaten Klaten berada pada usia yang produktif. Pada usia produktif peternak sapi perah diharapkan mampu menjalankan usaha ternak sapi perah dengan baik. Selain itu dengan usia yang produktif peternak mampu mengembangkan budidaya ternak sapi perah sehingga mampu menambah penghasilan keluarga.

\section{b. Jumlah Anggota Keluarga}

Berdasarkan Tabel 3 tersebut dapat diketahui bahwa seluruh responden mempunyai keluarga lebih dari 2 orang. Sehingga kegiatan dalam bertenak sapi perah hanya dikerjakan oleh anggota keluarga peternak tanpa menggunakan tenaga kerja lain. Dalam usaha ternak sapi perah 
Tabel 2. Jumlah dan Persentase Peternak Berdasarkan Umur di Desa Kayumas Kecamatan Jatinom Kabupaten Klaten

\begin{tabular}{lcr}
\hline Kelompok Umur (Th) & Jumlah Peternak & $\%$ \\
\hline $25-35$ & 6 & 20 \\
$36-45$ & 11 & 36,67 \\
$46-55$ & 9 & 30 \\
$56-65$ & 4 & 13,33 \\
\hline Jumlah & 30 & 100 \\
\hline
\end{tabular}

Sumber: Analisis Data Primer, 2010 dianalisis

Tabel 3. Jumlah dan Persentase Peternak Berdasarkan Jumlah Anggota Keluarga di Desa Kayumas Kecamatan Jatinom Kabupaten Klaten

\begin{tabular}{lcr}
\hline Anggota Keluarga & Jumlah Peternak & $\%$ \\
\hline $2-3$ & 10 & 33.33 \\
$4-5$ & 15 & 50 \\
$6-7$ & 5 & 16.67 \\
\hline Jumlah & 30 & 100 \\
\hline
\end{tabular}

Sumber: Analisis data Primer, 2010 dianalisis

Tabel 4. Jumlah dan Persentase Peternak Berdasarkan Tingkat Pendidikan di Desa Kayumas Kecamatan Jatinom Kabupaten Klaten

\begin{tabular}{lcr}
\hline Tingkat Pendidikan & Jumlah Peternak & $\%$ \\
\hline Tamat SD & 19 & 63,33 \\
Tamat SLTP & 8 & 26,67 \\
Tamat SLTA & 2 & 6,67 \\
S1 & 1 & 3,33 \\
\hline Jumlah & 30 & 100 \\
\hline
\end{tabular}

Sumber: Analisis data Primer, 2010 dianalisis

di Desa Kayumas sudah dikelola dengan baik mulai dari pemeliharaan ternak, pemberian pakan, sistem perkandangan, kesehatan ternak, pemerahan, sampai pemasaran hasil, karena dikelola secara langsung oleh anggota keluarga.

\section{c. Pendidikan Peternak}

Berdasarkan Tabel 4 dapat diketahui bahwa sebagian besar peternak responden adalah tamat SD. Hal ini menunjukkan walaupun dengan tingkat pendidikan yang rendah mereka dapat memahami bagaimana cara budidaya ternak sapi perah dengan baik dari pengalaman yang sudah bertahun-tahun.
Pengalaman yang diperoleh peternak responden dapat menjadi modal bagi peternak dalam menjalankan usaha ternaknya serta dalam pemilihan saluran pemasaran yang baik dan menguntungkan bagi peternak, sehingga peternak dapat memperoleh keuntungan yang sebesar-besarnya.

\section{d. Pengalaman Beternak Sapi Perah}

Keberhasilan usaha ternak sapi perah tidak hanya ditentukan oleh pendidikan saja tetapi juga ditentukan oleh pengalaman dalam beternak. Tabel 5 menunjukkan jumlah dan persentase peternak berdasarkan pengalaman 
berusaha ternak sapi perah di Desa Kayumas Kecamatan Jatinom Kabupaten Klaten.

Pengalaman usaha ternak menunjukkan lamanya waktu peternak dalam berusaha ternak serta proses pemasarannya. Berdasarkan pengalaman yang telah dimiliki oleh peternak diharapkan kedepannya peternak mampu lebih baik lagi sehingga dapat mempertahankan serta meningkatkan skala usahanya dan mampu meningkatkan pendapatannya.

\section{e. Jumlah Kepemilikan Ternak Sapi Perah}

Banyaknya kepemilikan ternak sapi perah (Tabel 6) menentukan besarnya pendapatan peternak. Semakin banyak jumlah sapi perah yang dimiliki oleh peternak maka jumlah produksi susu segar yang dihasilkan akan semakin banyak. Sehingga pendapatan peternak semakin meningkat.

\section{Identitas Lembaga Pemasaran}

Lembaga pemasaran yang terlibat dalam pendistribusian susu segar adalah pedagang pengumpul, pedagang perantara (KUD), dan pedagang pengecer. Karakteristik lembaga pemasaran susu segar pada pedagang pengumpul di Kecamatan Jatinom Kabupaten Klaten dilihat pada Tabel 7, dimana hanya terdapat dua pedagang pengumpul. Kedua umur pedagang pengumpul susu segar termasuk dalam kategori umur produktif yaitu 37 dan 38 tahun. Umur sangat berpengaruh terhadap kemampuan mereka dalam menjalankan perannya sebagai lembaga penyalur dalaml.pemasaran susu segar dari peternak ke konsumen.

Karakterßstik lembaga pemasaran susu segar pada pedagang perantara/KUD di Kecamatan Jatinom Kabupaten Klaten dilihat pada Tabel 8. Pedagang perantara/KUD termasuk dalam kategori umur produktif yaitu 45 tahun. Tingkat pendidikan pedagang lembaga pemasaran susu segar adalah tamat SLTA. Dengan tingkat pendidikan yang dimiliki responden lembaga pemasaran diharapkan dapat mengambil keputusan dengan baik dalam berdagang serta mampu membaca infomasi pasar yang ada sehingga memperlancar proses pemasaran yang dilakukan. Pengalaman mengusahakan pedagang susu segar selama 15 tahun. Dengan lamanya mengusahakan akan mudah bagi pedagang dalam memasarkan susu segar.

Berdasarkan Tabel 9 dapat diketahui bahwa terdapat tiga pedagang pengecer, dan ketiganya termasuk dalam kategori umur produktif. Dari segi pendidikan, dengan tingkat pendidikan yang dimiliki responden lembaga pemasaran diharapkan responden lembaga pemasaran dapat mengambil keputusan dengan baik dalam berdagang serta mampu membaca infomasi pasar yang ada sehingga memperlancar proses pemasaran yang dilakukan.

Lama berusaha akan mempengaruhi pengalaman dalam memasarkan susu segar. Semakin lama berusaha semakin mudah bagi pedagang dalam memasarkan susu segar. Hal ini disebabkan, pedagang yang sudah lama mengusahakan maka mereka akan lebih dikenal oleh konsumen sehingga jaringan pemasarannya akan semakin luas.

\section{Saluran Pemasaran}

Saluran pemasaran susu segar yang digunakan peternak sapi perah di Kecamatan Jatinom Kabupaten Klaten ada dua, yaitu:

Peternak $\rightarrow$ TPS $\rightarrow$ KUD $\rightarrow$ IPS, Home Industry, Pedagang Pengecer, dan Konsumen

Peternak $\rightarrow$ Pedagang Pengumpul $\rightarrow$ Pedagang Luar Kecamatan Jatinom.

Jika digambarkan saluran pemasaran susu segar yang digunakan peternak sapi perah di Kecamatan Jatinom tersaji seperti pada Gambar 1. 
Tabel 5. Jumlah dan Persentase Peternak Berdasarkan Pengalaman Berusaha Ternak Sapi Perah di Desa Kayumas

\begin{tabular}{lcr}
\hline Pengalaman (th) & Jumlah Peternak & $\%$ \\
\hline $10-12$ & 3 & 10 \\
$13-15$ & 8 & 26,67 \\
$16-18$ & 16 & 53,33 \\
$19-21$ & 2 & 6,67 \\
$>21$ & 1 & 3,33 \\
\hline Jumlah & 30 & 100 \\
\hline
\end{tabular}

Sumber: Analisis data Primer, 2010 dianalisis

Tabel 6. Jumlah dan Persentase Peternak Responden Berdasarkan Jumlah Sapi Perah di Desa Kayumas Kecamatan Jatinom Kabupaten Klaten

\begin{tabular}{lcr}
\hline $\begin{array}{l}\text { Jumlah Sapi Perah } \\
\text { (Ekor) }\end{array}$ & $\begin{array}{c}\text { Jumlah Peternak } \\
\text { (Orang) }\end{array}$ & $\%$ \\
\hline $2-4$ & 11 & 40 \\
$5-7$ & 14 & 43,34 \\
$8-10$ & 4 & 13,33 \\
$11-13$ & 1 & 3,33 \\
\hline Jumlah & 30 & 100 \\
\hline
\end{tabular}

Sumber: Analisis Data primer, 2010 dianalisis

Tabel 7. Identitas Lembaga Pemasaran Susu Segar pada Pedagang Pengumpul, di Kecamatan Jatinom Kabupaten Klaten

\begin{tabular}{|c|c|c|}
\hline Uraian & Pedagang Pengumpul & Persentase $(\%)$ \\
\hline \multicolumn{3}{|l|}{ Umur (tahun) } \\
\hline a. 37 & 1 & 50 \\
\hline b. 38 & 1 & 50 \\
\hline Jumlah & 2 & 100 \\
\hline \multicolumn{3}{|l|}{ Pendidikan } \\
\hline Tamat SD & 1 & 50 \\
\hline Tamat SLTP & - & - \\
\hline Tamat SLTA & 1 & 50 \\
\hline Jumlah & 2 & 100 \\
\hline \multicolumn{3}{|l|}{ Lama Berusaha } \\
\hline a. & 2 & 100 \\
\hline b. $\quad 4$ & - & - \\
\hline Jumlah & 2 & 100 \\
\hline
\end{tabular}

Sumber: Analisis data Primer, 2010 dianalisis 
Tabel 8. Identitas Lembaga Pemasaran Susu Segar pada Pedagang Perantara/KUD, di Kecamatan Jatinom Kabupaten Klaten

\begin{tabular}{lcc}
\hline Uraian & Pedagang Perantara & Persentase (\%) \\
\hline Umur (tahun) & 1 & 100 \\
45 & 1 & 100 \\
\hline Jumlah & 1 & 100 \\
\hline Pendidikan & 1 & 100 \\
Tamat SLTA & 1 & 100 \\
\hline Jumlah & 1 & 100 \\
\hline Lama Berusaha & 1 & \\
\hline Jumlah & 15 &
\end{tabular}

Sumber: Analisis data Primer, 2010 dianalisis

Tabel 9. Identitas Lembaga Pemasaran Susu Segar pada Pedagang Pengecer di Kecamatan Jatinom Kabupaten Klaten

\begin{tabular}{lcc}
\hline Uraian & Pedagang Pengumpul & Persentase (\%) \\
\hline Umur (tahun) & 1 & 33,33 \\
a.39 & 2 & 66,67 \\
b.40 & 3 & 100 \\
\hline Jumlah & & \\
\hline Pendidikan & 3 & 100 \\
Tamat SLTA & 3 & 100 \\
\hline Jumlah & & 33,33 \\
\hline Lama Berusaha & 1 & 66,67 \\
a.4-10 & 2 & 100 \\
b.10-16 & 3 & \\
\hline Jumlah & &
\end{tabular}

Sumber: Analisis data Primer, 2010 dianalisis

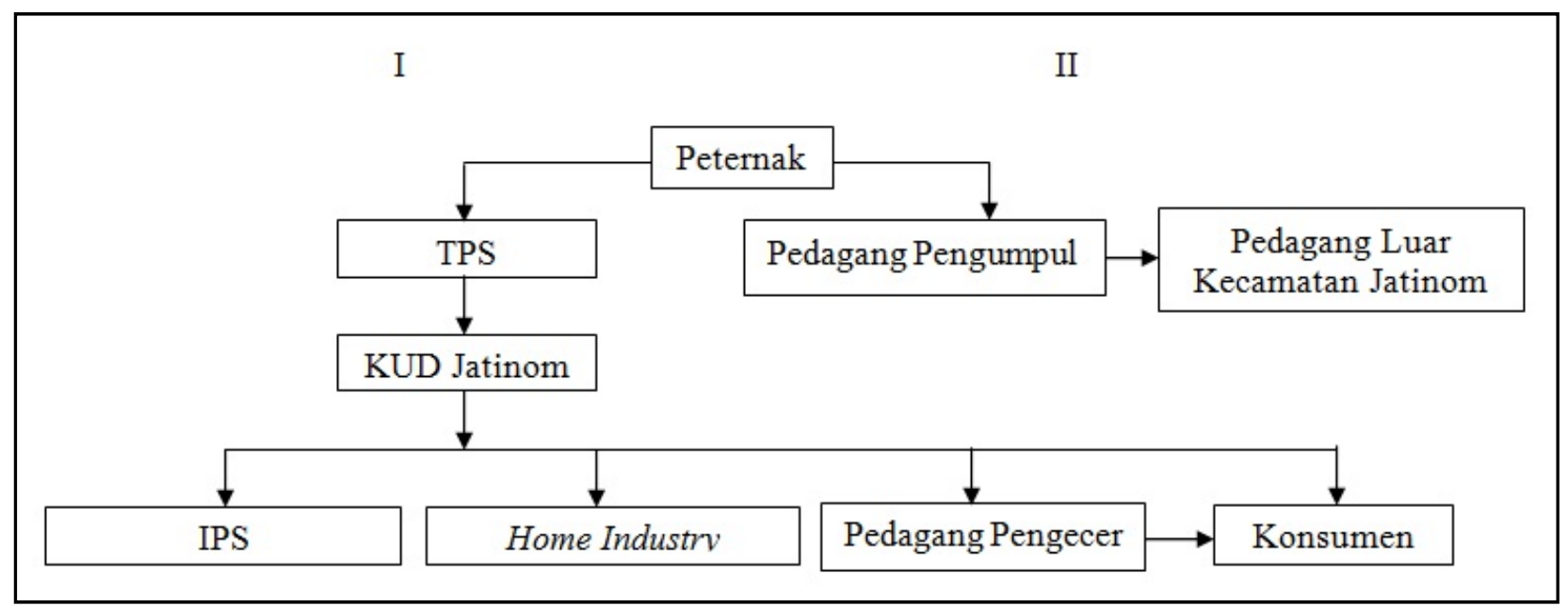

Gambar 1. Bagan Saluran Pemasaran Susu Segar di Kecamatan Jatinom Kabupaten Klaten 


\section{Biaya, Marjin dan Keuntungan Saluran Pemasaran}

Proses mengalirnya barang dari peternak ke konsumen memerlukan biaya, dengan adanya biaya pemasaran maka suatu produk akan lebih tinggi harganya. Semakin panjang rantai pemasaran maka biaya yang dikeluarkan dalam pemasaran akan semakin meningkat. Untuk mengetahui besarnya biaya, keuntungan dan marjin pemasaran susu segar pada saluran pemasaran I di Kecamatan Jatinom Kabupaten Klaten dapat dilihat pada Tabel 10.

Berdasarkan Tabel 10 pada saluran pemasaran I harga yang dibayar oleh KUD Jatinom ke responden peternak pada waktu penelitian harga terendah adalah $\mathrm{Rp} 2.793,00$ per liter dan harga tertinggi Rp 2.833,00 per liter sehingga rata-rata harga susu segar sebesar $\mathrm{Rp} 2.750,50$ per liter, harga yang dibayarkan KUD tergantung kualitas susu segar, dengan pembayaran oleh KUD Jatinom ke peternak secara bertahap dilakukan sebulan sebanyak tiga kali yaitu setiap tanggal 1, 11 dan 21. Selama proses pemasaran, peternak mengeluarkan biaya transportasi dan biaya penyusutan.

Biaya transportasi adalah biaya yang dikeluarkan peternak untuk menyetorkan susunya sampai ke TPS. Alat transportasi yang dipakai biasanya sepeda motor. Sedangkan biaya penyusutan adalah biaya yang dikeluarkan 23 peternak masing-masing seharga 2 liter susu untuk 10 hari penyetoran. Biaya pemasaran yang dikeluarkan oleh KUD meliputi biaya proses, biaya transportasi, biaya sanitasi, dan biaya operasional.

Jumlah biaya yang dikeluarkan oleh KUD Jatinom adalah sebesar Rp 185 per liter dari iuran anggota peternak perbulan, keuntungan pemasaran yang diperoleh KUD Jatinom adalah sebesar Rp 143,26 per liter. Sehingga diperoleh marjin pemasaran KUD Jatinom sebesar Rp 328,26 per liter. Biaya paling tinggi adalah biaya proses. Hal ini dikarenakan produk susu segar tidak tahan lama dan mudah rusak sehingga KUD Jatinom harus segera menampung susu yang dari peternak yang langsung dimasukkan ke cooling unit untuk proses pendinginan sampai suhu mencapai $2-4{ }^{\circ} \mathrm{C}$ ini dilakukan dengan tujuan untuk menghambat pertumbuhan bakteri dan mencapai standar kualitas yang dikehendaki IPS ,harga beli IPS Rp. 3.000,/liter sesuai dengan rata-rata standar kualitas TS $11,5 \%$ dan protein $2,65 \%$. Selain ke IPS, KUD Jatinom juga menjual langsung kepada home industry, pedagang pengecer, dan konsumen rumah tangga dengan harga $\mathrm{Rp}$. 3.000,- agar KUD tidak menanggung biaya resiko yang tinggi. Biaya terendah adalah biaya sanitasi, biaya ini dikeluarkan oleh KUD untuk membayar kebersihan alat yang ada di KUD Jatinom maupun di TPS seperti saringan, milk can, dan peralatan dalan pendinginan susu segar di KUD Jatinom. Total biaya pemasaran di peroleh dari penjumlahan biaya peternak dan biaya KUD Jatinom. Dari penjumlahan tersebut diperoleh total biaya pemasaran sebesar $\mathrm{Rp} 263,76$ per liter. Keuntungan pemasaran juga diperoleh dari keuntungan lembaga pemasaran yaitu sebesar Rp 143,26 per liter dan total marjin pemasaran adalah Rp 328,26 per liter.

Farmer's share merupakan bagian yang diterima peternak atau perbandingan antara harga yang diterima peternak/produsen dengan harga yang diterima konsumen. Farmer's share pada saluran pemasaran I adalah 89,06\% dan harga di tingkat konsumen adalah sebesar Rp. 3000 per liter. Dengan melihat nilai Farmer's share maka saluran pemasaran I efisien secara ekonomi.

Rata-rata biaya, keuntungan dan marjin pemasaran susu segar di Kecamatan Jatinom Kabupaten Klaten pada saluran pemasaran II dapat dilihat pada Tabel 11. Bardasarkan Tabel 11 dapat diketahui bahwa saluran pemasaran II produsen melibatkan peranan satu lembaga pemasaran yaitu pedagang pengumpul. Biaya transportasi pada saluran II lebih kecil dibandingkan pada saluran I, hal ini karena peternak yang menyetorkan susu segar ke pedagang pengumpul hanya tetangga sekitar rumah, sehingga jarak yang ditempuh oleh produsen tidak terlalu jauh. Pada saluran II susu segar dari produsen langsung dipasarkan kepada pedagang pengumpul. Kebanyakan produsen yang menggunakan saluran pemasaran II 
Tabel 10. Rata-Rata Biaya, Keuntungan dan Marjin Pemasaran Susu Segar di Kecamatan Jatinom Kabupaten Klaten Pada Saluran Pemasaran I

\begin{tabular}{|c|c|c|}
\hline \multirow{2}{*}{\multicolumn{3}{|c|}{$\begin{array}{l}\text { Uraian } \\
\text { Produsen/Peternak }\end{array}$}} \\
\hline & & \\
\hline a. Harga Jual dari Peternak & $2.750,50$ & 89,06 \\
\hline \multicolumn{3}{|l|}{ b. Biaya Pemasaran } \\
\hline 1). Biaya Transportasi & 47,05 & 1,57 \\
\hline 2). Biaya Penyusutan & 31,71 & 1,06 \\
\hline Jumlah Biaya & 78,76 & 2,63 \\
\hline c. Harga yang di terima di tingkat peternak & $2.671,74$ & 89,06 \\
\hline \multicolumn{3}{|l|}{ Koperasi Unit Desa (KUD) } \\
\hline a. Harga Beli Susu Segar & $2.750,50$ & 89,06 \\
\hline \multicolumn{3}{|l|}{ b. Biaya Pemasaran } \\
\hline 1). Biaya Proses & 77,00 & 2,57 \\
\hline 2). Biaya Transportasi & 30,00 & 1,00 \\
\hline Biaya Sanitasi & 68,00 & 2,27 \\
\hline 4). Biaya Operasional & 10,00 & 0,33 \\
\hline Jumlah Biaya & 185,00 & 6,17 \\
\hline c. Keuntungan Pemasaran & 143,26 & 4,78 \\
\hline d. Marjin Pemasaran & 328,26 & 10,94 \\
\hline e. Harga Jual & 3000,00 & 100,00 \\
\hline \multicolumn{3}{|c|}{ IPS dan Home Industry, Pedagang Pengecer, dan } \\
\hline Harga Beli & 3000,00 & 100,00 \\
\hline Total Biaya Pemasaran & 263,76 & 8,79 \\
\hline Total Keuntungan & 143,26 & 4,78 \\
\hline Total Marjin Pemasaran & 328,26 & 10,94 \\
\hline Bagian yang diterima peternak & & 89,06 \\
\hline
\end{tabular}

Sumber: Analisis Data Primer, 2010 dianalisis

beralasan karena peternak yang dulu ditolak untuk disetor ke KUD dapat diterima di pedagang pengumpul, dan peternak juga memasarkan susu segarnya melalui pedagang pengumpul karena harga susu segar yang ditawarkan pedagang pengumpul lebih tinggi dari pada harga dari KUD, dengan kualitas yang berbeda, harga ditingkat peternak tetap sama dan hasil dari peternak dapat ditampung semua, tanpa ada yang ditolak. Total biaya pemasaran pada saluran pemasaran II Rp 52,93 per liter. Biaya ini diperoleh dari penjumlahan peternak dan lembaga pemasaran dan total keuntungan dari saluran pemasaran II sebesar Rp 60,07 per liter sehingga marjin pemasarannya sebesar $\mathrm{Rp} 81,50$ per liter. Marjin pemasaran ini diperoleh dari penjumlahan total biaya pemasaran dengan total keuntungan pemasaran.
Farmer's share adalah bagian yang diterima peternak produsen, semakin besar nilai farmer's share dan semakin kecil marjin pemasaran maka pemasaran dapat dikatakan efisien. Pada saluran pemasaran II nilai farmer's share sebesar 97,24\% dan harga yang diterima konsumen sebesar Rp 2950,per liter. Pada saluran pemasaran II memiliki marjin pemasaran yang lebih rendah dan farmer's share yang lebih tinggi dibandingkan dengan saluran pemasaran I. Sehingga dapat dikatakan saluran pemasaran II lebih efisien secara ekonomi dibandingkan dengan saluran pemasaran I.

\section{Efisiensi Pemasaran Susu Segar}

Menurut Mubyarto (1995), analisis pemasaran dianggap efisien apabila dianggap 
Tabel 11. Rata-Rata Biaya, Keuntungan dan Marjin Pemasaran Susu Segar di Kecamatan Jatinom Kabupaten Klaten Pada Pola Saluran Pemasaran II

\begin{tabular}{|c|c|c|}
\hline Uraian & Rp/liter & $\%$ \\
\hline \multicolumn{3}{|l|}{ Produsen/Peternak } \\
\hline a. Harga Jual dari Peternak & 2900,00 & 97,24 \\
\hline \multicolumn{3}{|l|}{ b. Biaya Pemasaran } \\
\hline Biaya Transportasi & 31,50 & 1,07 \\
\hline Jumlah Biaya & 31,50 & 1,07 \\
\hline c. Harga yang di Terima ditingkat Peternak & 2868,50 & 97,24 \\
\hline \multicolumn{3}{|l|}{ Pedagang Pengumpul } \\
\hline a. Harga Beli & 2900,00 & 97,24 \\
\hline b. Biaya pemasaran & & \\
\hline Biaya Tenaga Kerja & 21,43 & 0,73 \\
\hline c. Keuntungan & 60,07 & 2,00 \\
\hline d. Marjin Pemasaran & 81,50 & 2,72 \\
\hline 5). e. Harga Jual & 2950,00 & 100,00 \\
\hline \multicolumn{3}{|l|}{ Konsumen Luar Kecamatan Jatinom } \\
\hline Harga Beli Konsumen & 2950,00 & 100,00 \\
\hline a. Total Biaya Pemasaran & 52,93 & 1,09 \\
\hline b. Total Keuntungan & 60,07 & 2,00 \\
\hline c. Total Marjin Pemasaran & 81,50 & 2,72 \\
\hline $\begin{array}{l}\text { d. Bagian yang diterima peternak } \\
\text { (Farmer's Share) }\end{array}$ & & 97,24 \\
\hline
\end{tabular}

Sumber: Analisis Data Primer, 2010 dianalisis

Tabel 12. Efisiensi Ekonomi Saluran Pemasaran Susu Segar

\begin{tabular}{lrr}
\hline Saluran Pemasaran & Saluran I & Saluran II \\
\hline Total Biaya (Rp/Liter) & 263,76 & 52,93 \\
Total Keuntungan (Rp/Liter) & 143,26 & 60,07 \\
Marjin Pemasaran (Rp/Liter) & 328,26 & 81,60 \\
Farmer's Share (\%) & 89,06 & 97,24 \\
\hline
\end{tabular}

Sumber: Analisis Data Primer, 2010 dianalisis

mampu menyampaikan hasil dari produsen kepada konsumen dengan biaya wajar serta mampu mengadakan pembagian yang adil dari keseluruhan harga yang dibayarkan konsumen Untuk mengetahui efisiensi pemasaran susu segar secara ekonomis adalah dengan melihat marjin dan bagian yang diterima peternak (farmer's share) pada setiap saluran pemasaran yang ada. Efisiensi ekonomis pemasaran susu segar di Kecamatan jatinom dapat dilihat pada Tabel 12, dimana saluran pemasaran I memiliki marjin pemasaran yang lebih tinggi dibandingkan saluran pemasaran II. Hal ini karena pada saluran pemasaran I melibatkan peranan lembaga pemasaran, dimana lembaga pemasaran tersebut mengeluarkan biaya pemasaran serta penetapan tingkat keuntungan yang berakibat pada semakin tingginya margin dan keuntungan pemasaran, serta nilai bagian yang diterima produsen semakin rendah. Berdasarkan tinggi rendahnya marjin pemasaran dan farmer's share maka saluran pemasaran II lebih efisien secara ekonomis di Desa Kayumas Kecamatan Jatinom Kabupaten Klaten. Hal ini dikarenakan nilai farmer's share dari saluran pemasaran II lebih tinggi dibandingkan dengan saluran pemasaran I. 


\section{KESIMPULAN}

Berdasarkan hasil penelitian dapat diambil kesimpulan :

1. Pemasaran susu segar di Kecamatan Jatinom Kabupaten Klaten melalui dua saluran. Saluran Pemasaran I: Peternak $\rightarrow$ TPS $\rightarrow$ KUD $\rightarrow$ IPS, Home Industry, Pedagang Pengecer, dan Konsumen. Saluran Pemasaran II: Peternak $\rightarrow$ Pedagang Pengumpul $\rightarrow$ Pedagang Luar Kecamatan Jatinom.

2. Pada saluran I total biaya pemasaran adalah Rp 263,76 per liter, total keuntungan pemasaran Rp 143,26 per liter, dan marjin pemasaran Rp 328,26 per liter. Untuk saluran pemasaran II total biaya pemasaran Rp 52,93 per liter, total keuntungan pemasaran Rp 60,07 per liter, dan marjin pemasaran $\operatorname{Rp} 81,50$ per liter.

3. Kedua saluran pemasaran secara ekonomi efisien dengan nilai farmer's share pada saluran pemasaran I $89,06 \%$ dan saluran pemasaran II sebesar 97,24 \%.

\section{DAFTAR PUSTAKA}

Abadi, F. N. 2007. Analisis Pemasaran Keripik Tempe di Kecamatan Sambungmacan Kabupaten Sragen. Skripsi S1 Program Studi Sosial Ekonomi Pertanian/Agrobisnis Fakultas Pertanian Universitas Sebelas Maret Surakarta. Tidak Dipublikasikan.

Khotimah, K. 2009. Pembuatan Susu Bubuk Dengan Foam-Mat Drying : Kajian Pengaruh Bahan Penstabil Terhadap Kualitas Susu Bubuk. http:// peperonity.com. Diakses 10 Januari 2010.

Mubyarto . 1995. Pengantar Ekonomi Pertanian. LP3ES. Jakarta.

Nur, R., Muh. Amir. S., dan Kartika. E. 2007. Analisis Margin Pemasaran Telur Itik di Kelurahan Borongloe Kecamatan Bontomarannu Kabupaten Gowa. Jurnal Agrisistem. Vol. 3. No 1. Juni 2007.

Sudono, A., Fina. R., dan Budi S.S. 2003. Beternak Sapi Perah Secara Intensif. PT Agromedia Pustaka. Jakarta. 